Henryk Depta

Uniwersytet Warszawski

\title{
O humanistyczną wrażliwość nauczyciela sztuki
}

Polska koncepcja wychowania estetycznego ujmuje to wychowanie jako wychowanie przez sztukę i wychowanie do sztuki. Nieco upraszczając można powiedzieć, że w wychowaniu przez sztukę sztuka jest narzędziem wychowania - wychowania całego człowieka - zaś w wychowaniu do sztuki jest ona przedmiotem poznania. Te dwa - jak zostały one przez Irenę Wojnar określone - zakresy wychowania estetycznego stanowią wzajemnie powiązaną i uzależnioną od siebie całość ${ }^{1}$. Przyjmujemy, że wychowanie do sztuki czyli kształcenie tzw. kultury estetycznej, stanowi wstępny warunek rozwiniętego i skutecznego wychowania przez sztukę. Równocześnie jednak uznajemy, że racja wychowania do sztuki jest tylko wtedy racją pedagogicznie uzasadnioną, gdy służy ono wychowaniu przez sztukę.

Powszechne jest przekonanie, że wychowanie estetyczne - zarówno wychowanie przez sztukę, jak i wychowanie do sztuki - wymaga uprzystępniającej sztukę aktywności podejmowanej przez - jak go określił Stefan Szuman - wychowawcę estetycznego. W wychowaniu przez sztukę rola tego wychowawcy polega na udzieleniu pomocy w odkrywaniu, odczuwaniu i uwewnętrznieniu zawartych w dziełach sztuki estetycznych i pozaestetycznych - zwłaszcza poznawczych i moralnych - wartości. W wychowaniu do sztuki działania wychowawcy estetycznego skupione są przeważnie na dostarczaniu odpowiedniej wiedzy o sztuce. Wyraża się nadzieję, że dzięki tej właśnie wiedzy dzieła sztuki zostaną właściwie (?) zrozumiane i sprawiedliwie ocenione. Krzysztof Pomian jest tego całkowicie pewien, gdy stwierdza:

Wszelkiej sztuki trzeba się uczyć, bo nikt nie rodzi się genetycznie wyposażony w umiejętność widzenia ze zrozumieniem obrazów, rzeźb, budynków i in-

\footnotetext{
${ }^{1}$ Por.: I. Wojnar, Teoria wychowania estetycznego - zarys problematyki, wyd. 4, Warszawa 1995.
} 
nych dzieł [...] Analfabetyzm nie zniknie bez artystycznego wychowania społeczeństwa².

Takiemu stanowisku można jednak przeciwstawić opinię tych, którzy - jak to już przeszło 2000 lat temu uznał Cyceron - uważają, że:

Wszyscy ludzie choćby nie znali sztuki i jej zasad, umieją sądzić ukrytym jakimś zmysłem, co jest dobrego, co złego w dziełach sztuki i jej zasadach; a gdy umieją sądzić o obrazach, o posągach i o płodach innych sztuk, do oceniania których mniej zdolności od natury odebrali, to daleko łatwiej sądzić mogą o słowach, rytmach i tonach, bo te się osądzić dają wrodzonym wszystkim ludziom czuciem, którego natura nikomu zupełnie nie odmówiła ${ }^{3}$.

Można powiedzieć jeszcze mocniej i uznać, że sztuka przemawia siłą swojej magii, że wiedza o sztuce nie tyle pomaga, ile przeszkadza w jej autentycznym przeżywaniu i oddziaływaniu. Taki pogląd wyraża wielu artystów zrażonych i urażonych tymi opiniami i ocenami, które na temat ich utworów wydają teoretycy i krytycy sztuki. Dla wielu artystów te opinie i oceny to pustosłowie do sztuki wcale nie zbliżające, ale przeciwnie, sztuce ubliżające. Taki pogląd wyraził Oscar Wilde, stwierdzając, że istnieją dwa sposoby nielubienia sztuki: pierwszy to jej nie lubić, a drugi to lubić ją racjonalnie. Podobnie Pablo Picasso uznał, że o sztuce nie należy mówić, można ją kochać, albo nie lubić. Tego „pustosłowia”, czy łagodniej, tej bezradności rozważań o sztuce świadomi są także niektórzy teoretycy sztuki. I tak Max Friedländer stwierdza:

Tak jak nie można stworzyć dzieła sztuki na podstawie wiedzy, tak też nie da się z pomocą słów dzieła zrozumieć. Choć będziemy z powodzeniem wysubtelniać unaoczniającą, charakteryzującą wymowę słów, nigdy nie pokryje się ona całkowicie z wrażeniem, jakie wywołuje dzieło sztuki. Zawsze to, co rozstrzygające, pozostaje niewypowiedziane. Jeżeli tworzenie sztuki i jej kontemplacja są tym samym - a w pewnym sensie są - to przecież uczoność chwyta tylko szatę, a nie ciało, albo ciało, a nie duszę dzieła. Poznając dzieło miłośnik sztuki jest platonicznym artystą, uczestniczy w duchowym działaniu twórcy. Jako mówca jąka się, zawodzi jako nauczyciel ${ }^{4}$ [podkreślenie moje - H.D.].

Pogląd, że wszelka wiedza o sztuce jest, mówiąc najłagodniej, wiedzą nietrafioną, wypływa z przekonania - przywołajmy J. W. Goethego - że

\footnotetext{
${ }^{2}$ K. Pomian, $W$ błysku reklam, w świetle laserów, „Gazeta Wyborcza” („Świąteczna”), 21-22 marca 2004, s. 20.

${ }^{3}$ Cyceron, De oratore III, 50, 195. Cyt. za: W. Tatarkiewicz, Estetyka starożytna, wyd. 2 przejrzane i uzupełnione, Wrocław-Warszawa-Kraków 1962, s. 252.

${ }^{4}$ M. Friedländer, O granicach nauki w sztuce, [w:] Pojęcia, problemy, metody wspótczesnej nauki o sztuce. Dwadzieścia sześć artykułów uczonych europejskich i amerykańskich, wybrał, przekłady przejrzał, wstępem opatrzył J. Białostocki, Warszawa 1976, s. 165.
} 
„sztuka jest przekazicielką rzeczy niewypowiedzianych; dlatego wydaje się niedorzecznością chcieć ją znowu przekazać za pomocą słów”" Ten wielki poeta stwierdził jednak równocześnie, że ten trud „przekazywania sztuki” należy jednak podjąć. O pożytku mówienia i pisania o sztuce przekonany był także Witold Lutosławski:

Jestem pewien, że trzeba myśleć, mówić i pisać o muzyce. Nie wierzę, że komuś uda się kiedyś zgłębić jej istotę, ale nawet błądzenie wokół jakiegoś zjawiska nierozszyfrowanego, niemożliwego do pełnego zrozumienia, ale błądzenie przybliżające, przeczuwające, odgadujące ma swój głęboki sens ${ }^{6}$ [podkreślenia moje - H.D.].

Dopowiedzmy: określona i w określony sposób przekazana wiedza o sztuce potrzebna jest także miłośnikowi sztuki. Powinna to być jednak taka wiedza, która przekazana zostanie „w trybie osobistego zainteresowania, a nie w trybie naukowego znawstwa" charakteryzuje często krytykę artystyczną, dla której - jak sarkastycznie zauważył to Bogdan Suchodolski - „najważniejszą wartością sztuki jest to, że umożliwia istnienie krytyki"8. Chodzi więc o to, aby wiedza o sztuce autentycznie do sztuki zbliżała, aby wzbogacała i pogłębiała jej własne (!) przeżycie.

Potrzebę przekazania takiej wiedzy uzasadnić można nie tylko i nie tyle tym, że nikt nie rodzi się genetycznie wyposażony w umiejętność odbioru sztuki (w tej bowiem sprawie można być odmiennego zdania), ile tym, że w naszych czasach niepomiernie rozszerzył się świat sztuki. Współcześnie w stopniu o wiele większym aniżeli stosunkowo jeszcze niedawno mamy okazję zetknięcia się ze sztuką powstałą nie tylko w naszych czasach i w naszym obszarze kulturowym, ale także w epokach historycznie odległych oraz w geograficznie dalekich, często egzotycznych kręgach kulturowych. Można, oczywiście, powiedzieć, że „język” sztuki niezależnie od czasu i miejsca jej powstania jest uniwersalny i zrozumiały dla wszystkich. Niemniej prawdą jest także, że w określonych epokach i kręgach kulturowych wypracowane zostały odpowiednie poetyki i konwencje nie zawsze

\footnotetext{
${ }^{5}$ J. W. Goethe, Refleksje i maksymy, przeł., oprac. i wstępem opatrzył J. Prokopiuk, Warszawa 1977, s. 196.

${ }^{6}$ O roli słowa, teatralności i tradycji w muzyce - mówi Witold Lutosławski, [w:] B. Pociej, Lutosławski a wartość muzyki, Warszawa 1976, s. 133.

${ }^{7}$ B. Suchodolski, Współczesne problemy wychowania estetycznego, [w:] I. Wojnar (red.), Wychowanie przez sztukę, Warszawa 1965, s. 18.

${ }^{8}$ B. Suchodolski, Uspołecznienie kultury, wyd. 2 zmienione i powiększone, Warszawa 1947, s. 214 .
} 
dla współczesnego człowieka wystarczająco przejrzyste i uchwytne. W tej sytuacji uzasadniona jest nadzieja, że wiedza o sztuce tych odległych epok i kultur pozwoli na jej adekwatne odczytanie i pełniejsze przeżycie.

Ważną przyczyną uzasadniającą potrzebę wychowania do sztuki jest niespotykana wcześniej na tak wielką skalę inwazja kiczu, czyli - odważmy się nazwać rzecz po imieniu - złej sztuki. Oczywiście znowu można powiedzieć, że dopiero czas - ten ostateczny i sprawiedliwy weryfikator - rozstrzygnie, jaka sztuka za dobrą, za prawdziwą uznana zostanie. Trudno jednak nie zauważyć, że świat sztuki współczesnej to - mówiąc obrazowo - ogród jeszcze nieplewiony, w którym obok roślin szlachetnych pełno także chwastów. Obok utworów głębokich i przejmujących wiele zwyczajnego bełkotu i szalbierstwa. Tak zresztą było i dawniej, z tym że w naszych czasach ogromnie zwiększyła się powierzchnia tego ogrodu, czy - jak się go także nazywa - supermarketu sztuki. Trudno całkowicie zgodzić się z przez Clementa Greenberga przedstawioną, a przez Theodora Adorno powtórzoną i upowszechnioną diagnozą, zgodnie z którą sztuka współczesna rozpięta jest pomiędzy kiczem a awangardą. Tę diagnozę podważywszy, stwierdzić jednak należy, że w tym nieplewionym ogrodzie sztuki współczesnej kicz wyjątkowo obficie się rozplenił, zaś tą jego grzędą, na której bezczelnie się panoszy i bezwstydnie mizdrzy, są środki masowego przekazu. Czy jest tak dlatego, że kicz podobnie jak środki masowego przekazu odwołuje się do tego i temu schlebia, co w nas... kiczowate właśnie? Przyznajmy: kicz uderza w pewne trwałe, ale i najbardziej prymitywne struny naszej psychiki. Dlatego, że trwałe - jest tak silny. Dlatego, że tak prymitywne - jest tak groźny. Dlatego kicz - ta słodka trucizna - jest tak ludzki i zarazem tak nieludzki. Ważne zadanie wychowania estetycznego polega na „walce” z kiczem - zarówno z tym, który przejawia się w różnorodnych utworach, jak i z tym, który szarogęsi się w ślepych zaułkach naszej wyobraźni.

Można wskazać jeszcze jedną przyczynę uzasadniającą ważną rolę nauczyciela sztuki. Związana jest ona z reakcją, mówiąc zaś dokładniej: z brakiem pozytywnej reakcji na sztukę współczesną, i to właściwie na wszystkie jej dziedziny. Ciągle można usłyszeć: nie rozumiem współczesnej plastyki, nie rozumiem współczesnej poezji, nie rozumiem współczesnej muzyki itd. Według José Ortegi y Gasseta, sztuka współczesna stała się niezrozumiała, ponieważ zmierza do dehumanizacji, czyli do „stopniowej eliminacji elementów ludzkich”. Treść odnosząca się do człowieka stała się „tak nikła, 
że prawie niezauważalna" . Już nie zajmuje się człowiekiem, ale sama sobą. Mówi nie o bólu istnienia, ale o bólu tworzenia, nie o ludzkiej kondycji, ale, przeważnie nie najlepszej, kondycji artysty. Taka sztuka jest zrozumiała tylko dla ludzi umiejących dostrzec jej wartość artystyczną. Dla zwykłych ludzi jest niedostępna. „Nowa sztuka jest sztuką dla artystów”. Stosunkowo najczęściej mówi się o niezrozumiałości tzw. malarstwa abstrakcyjnego. Jest cząstka prawdy w konstatacji Pablo Picassa: „Sztuka abstrakcyjna jest tylko malowaniem. A co z dramatem?"10. W tym abstrakcyjnym malarstwie wiele rzeczywiście często artystycznej szarlatanerii. Trwa ono jednak zbyt długo i wydało rzeczywiste arcydzieła, aby mogło zostać całkowicie odrzucone czy zlekceważone. Uznanie i „zrozumienie” tego malarstwa wymaga jednak zdecydowanej zmiany w naszej śródziemnomorskiej kulturze z silnie utrwalonym poglądem, że „zrozumiałe” są tylko obrazy realistyczne. Warto i tutaj wysłuchać P. Picassa:

Wszyscy zrozumieć chcą malarstwo. Czemu nie próbują zrozumieć śpiewu ptaków. Dlaczego kocha się noc, kwiat, wszystko, co nas otacza, nie usiłując tego zrozumieć? Tylko malarstwo chcą ludzie zrozumieć. Niechże przede wszystkim zrozumieją, że artysta działa z konieczności, że i on jest mikroskopijną cząstką świata, której nie trzeba przypisywać więcej znaczenia niż tylu przejawom natury, które nas zachwycają, ale których sobie nie tłumaczymy. Ci, co dążą do wytłumaczenia obrazów, zwykle schodzą na manowce ${ }^{11}$.

„Schodzą na manowce”, ponieważ cała trudność - i całe szczęście! - polega na tym, że znaczenie dzieła sztuki pozostaje otwarte, że nie ma tylko jednego jego „wytłumaczenia”. Ta płodna wieloznaczność dzieła sztuki sprawia, że możliwe są różnorakie jego konkretyzacje i interpretacje. Im bogatsze jest to dzieło, tym większe otwiera się pole dla takich konkretyzacji i interpretacji, tym większe są szanse, aby także odbiorca stał się współtwórcą. Można tutaj mówić o swoistym paradoksie estetycznym. Dzieło sztuki wymaga bowiem - z jednej strony - pokory i uległości oraz - z drugiej strony - niezależności i odwagi. Pokory i uległości, czyli dobrej woli, pewnej cierpliwości wyrażającej się w gotowości wniknięcia w złożoną materię dzieła sztuki. Jest to warunek każdego rzeczywistego odbioru, który trafia, „uderza” w dzieło, a nie jest tylko odległą od niego projekcją odbiorcy. Równocześnie jednak dzieło sztuki wymaga niezależności i odwagi potrzebnej po

\footnotetext{
${ }^{9}$ J. Ortega y Gasset, Dehumanizacja sztuki i inne eseje, przeł. P. Niklewicz, wybrał i wstępem opatrzył S. Cichowicz, Warszawa 1980, s. 286.

${ }^{10}$ P. Picasso, Rozmowa z Christianem Zervos, [w:] Artyści o sztuce. Od van Gogha do Picassa, wybrały i oprac. E. Grabska i H. Morawska, Warszawa 1962, s. 553.

${ }^{11}$ Ibidem, s. 558.
} 
to, aby nie pozwolić „opętać” się przedstawionej w utworze wizji, nie zlęknąć się własnej interpretacji. Wydaje się, że ta właśnie dialektyka pokory i odwagi stanowi charakterystyczną właściwość przeżycia estetycznego. To ona sprawia, że odbiorca równocześnie odbiera i współtworzy dzieło sztuki. To współtworzenie polega na wydobyciu jego różnorodnych wartości i znaczeń oraz zbudowaniu z nich własnej wizji, współbrzmiącej z wizją autora, ale ożywionej - jeżeli można tak powiedzieć - „grupą krwi” wyobraźni odbiorcy. To dzięki odbiorcy dzieło zaczyna żyć własnym życiem. To właśnie on, odbiorca - każdy na swój sposób - „wieńczy” dzieło.

Czy takiego twórczego odbioru dzieła sztuki można i należy uczyć? Pozytywnej - mimo pewnych zastrzeżeń - odpowiedzi na to pytanie udzielił Stefan Szuman. Uznał on, że język artystyczny, chociaż dostatecznie jasny i wyrazisty oraz jeżeli chodzi o arcydzieła - nieomylnie, trafnie i przekonująco wyrażający swoją treść, nie zawsze i nie od razu jest dla wszystkich zrozumiały. Dlatego: „Tego swoistego języka - innego od wszystkich języków - trzeba się uczyć, aby w pełni wyczerpać i przeżyć treść, którą wyraża. Należy się go uczyć stopniowo, starannie, wnikliwie, tak jak każdego języka"12. W uczeniu się tego języka konieczny jest pośrednik, to znaczy - jak go nazywa S. Szuman - wychowawca estetyczny. Wspomagając wychowanków w uzyskaniu najpełniejszego odbioru sztuki, nie powinien on jednak wyręczać dzieła sztuki w jego głęboko poruszającym oddziaływaniu. Jego rola polega na uprzystępnianiu sztuki, czyli podjęciu „tych czynności wychowawczych, za pomocą których wytwarzamy u kogoś zainteresowanie i zapotrzebowanie na sztukę oraz zdolność właściwego jej spostrzegania, rozumienia i przeżywania"13. Według S. Szumana, uprzystępnianie sztuki polega na prowadzeniu umiejętnej rozmowy z odbiorcą o utworze. Czy jednak taka rozmowa ograniczyć sie powinna do „obiektywnej analizy utworu”? Czy taka „obiektywna analiza” nie prowadzi do zniszczenia niepowtarzalności dzieła sztuki i standaryzacji jego odbioru? Prawdą jest bowiem, że analiza równocześnie zbliża i oddala od dzieła sztuki. Nie można tutaj ustalić jednego tylko kierunku postępowania. Różne powinny być poziomy tej analizy. Można i należy wykorzystać różne metody uwzględniające, $\mathrm{z}$ jednej strony, konkretne dzieło sztuki oraz, z drugiej strony, konkretnego odbiorcę. Zakres i kierunek analizy wyznaczać każdorazowo powinny stopień złożoności dzieła sztuki oraz możliwości percepcyjne odbiorcy.

\footnotetext{
${ }^{12}$ S. Szuman, O sztuce $i$ wychowaniu estetycznym, Warszawa 1969, s. 21.

${ }^{13}$ Ibidem, s. 23.
} 
Zawsze jednak zmierzać powinniśmy do tego, aby była to taka analiza, która stwarza pole do własnej interpretacji. Odpowiednio dokonana analiza utworu, pomagając $w$ jego zrozumieniu, ułatwia interpretację, wcale jednak o niej do końca nie przesądza. Interpretacja ściśle związana $\mathrm{z}$ własną oceną wyraża uczuciowo zabarwiony stosunek odbiorcy do utworu. Wielkość wybitnych dzieł sztuki na tym również polega, że umożliwiają one różne, nawet przeciwstawne interpretacje. Ta właśnie możliwość różnorakich odczytań - wynikająca konsekwentnie z wieloznaczności dzieła sztuki - sprawia, że interpretacja jest raczej sztuką aniżeli umiejętnością i podobnie jak sztuka wymaga wyobraźni. Droga autora dzieła do odbiorcy jest bowiem drogą - przez to dzieło - od wyobraźni do wyobraźni.

Uprzystępnianie sztuki nie jest więc sprawą łatwą. Zmierzać ono powinno do tego, aby dzieło sztuki zostało przeżyte, a nie użyte (i nadużyte!). Musimy o tym pamiętać szczególnie podczas szkolnych, niestety często uproszczonych - używając terminologii tradycyjnej metodyki - „rozbiorów” dzieła sztuki. Szczególną uwagę należy poświęcić temu, aby w naszych uprzystępniających sztukę działaniach nie doszło do jej pedagogicznej pacyfikacji. Do takiego „pedagogicznego ukąszenia” dochodzi zwłaszcza wtedy, gdy wartość moralna sztuki zdegradowana zostaje do prymitywnej moralistyki. Podobnie zminimalizowana i zniekształcona może zostać wartość poznawcza sztuki. „O czym pisarz chciał powiedzieć - pyta pani od polskiego. Chciał pokazać nierówności kapitalizmu wczesnego”. Tak w swoim czasie śpiewał Kazik (Kazimierz Staszewski). Takiego pytania „pani od polskiego” w naszej zmienionej rzeczywistości raczej już nie zadaje. Jeszcze jednak stosunkowo niedawno program nauczania języka polskiego zalecał, aby na Lalkę Bolesława Prusa spojrzeć jako na „obraz społeczeństwa polskiego II połowy XIX wieku”. Aktualnie obowiązujący program już takich sugestii nie zawiera, ale to wcale nie oznacza, że ujmowanie dzieła literackiego jako prostego odbicia rzeczywistości należy już do przeszłości. Mała stosunkowo strata, gdy okazją do takiego ujęcia stają się utwory, które zaliczyć raczej można do zbeletryzowanej publicystyki aniżeli do sztuki (wtedy jednak można zapytać, dlaczego znalazły się one w programie wychowania literackiego). O wiele gorzej, gdy ofiarą takiej obróbki stają się wielkie dzieła literatury polskiej. Wtedy zresztą wypaczeniu ulega nie tylko dzieło literackie, ale także wiedza o rzeczywistości, którą dzięki temu dziełu usiłuje się przekazać. Zrezygnujmy więc z ujmowania sztuki jako środka do przekazywania wyraźnie określonej wiedzy oraz rozwinięcia równie wyraź- 
nie określonych, najczęściej zmienną koniunkturą wyznaczonych postaw i przekonań (moralnych, społecznych, politycznych itd.). Ten grzech obciąża szczególnie wychowanie literackie. Wychowanie plastyczne oraz wychowanie muzyczne zdołały się już bowiem częściowo uwolnić od tego rodzaju uproszczeń. W dziełach sztuki plastycznej oraz - w jeszcze większym stopniu - w utworach muzycznych ich autonomiczne właściwości oraz autentyczne wartości są bowiem bardziej zauważalne. O tej zdecydowanie lepszej sytuacji szkolnego wychowania plastycznego i szkolnego wychowania muzycznego rozstrzyga również to, że ich programy obejmują także własną - plastyczną i muzyczną - aktywność dzieci i młodzieży, co pozwala na dostrzeżenie i przeżycie specyficznych właściwości sztuki. W tych programach znaleźli również miejsce - wymieniając tylko przykładowo - Michał Anioł i Rembrandt, Bach i Mozart. Tymczasem mimo obecności literatury w szkole od pierwszej do ostatniej klasy można ukończyć szkołę średnią nie przeczytawszy żadnego utworu A. Czechowa czy T. Manna. W wychowaniu literackim musi się więc znaleźć miejsce dla wielkiej literatury. Bez tej literatury trudno bowiem mówić o, w pełnym tego słowa znaczeniu, wychowaniu literackim.

To można stosunkowo łatwo zrobić. Potrzebna jest bowiem tylko odpowiednia decyzja. Oczywiście nie chodzi o rezygnację z literatury polskiej. Przeciwnie: powinna ona zająć tę pozycję, na którą zasługuje. Nie powinna to być jednak literatura „słuszna”, tzn. odpowiadająca aktualnej polityce państwa, ale - po prostu - literatura dobra. Takie zaś są niewątpliwie wielkie dzieła polskiego romantyzmu, pozytywizmu i Młodej Polski. Zobaczmy jednak w tych dziełach nie tylko i nie tyle dzieje narodu (zgodnej z prawdą tej wiedzy niech dostarczają lekcje historii!), ale dzieje człowieka. Nie tylko i nie tyle to, jak naród walczył o swoją niepodległość, ale także to, jak człowiek walczył o niepodległość swojej egzystencji. Te zawsze żywe, uniwersalne wartości są obecne i w Dziadach, i w Lalce, i w Weselu. Ta uniwersalna problematyka tych arcydzielnych utworów zostaje jednak ciągle jeszcze w ich szkolnej jednostronnej recepcji jeżeli nie całkowicie pominięta, to poważnie zagłuszona. Dzieła te zostają - w dosłownym tego słowa znaczeniu - przerobione. Przerobione na szaro! Prawdziwie uprzystępnić te utwory, to ujawnić pełną, bogatą paletę ich znaczeń, otworzyć umysły i serca na ich autentyczne wartości.

Obok tych działań, które sprzyjają głębszemu uchwyceniu i uwewnętrznieniu autentycznych wartości sztuki, ważne są także te działania nauczy- 
ciela, które służą inspiracji i stymulacji własnej aktywności dzieci i młodzieży. Twórcza działalność dzieci jest właściwą dla ich wieku formą wyrażania samego siebie oraz ich własnego stosunku do świata. Możliwości dyskursywnego, pojęciowego ujęcia rzeczywistości nie są bowiem w tym wieku jeszcze wystarczająco rozwinięte. W tej twórczej działalności - malarskiej, muzycznej, teatralnej - dzieci poruszają się o wiele swobodniej. Jest to ich naturalny język. Naturalny środek wyrazu i komunikacji. Takim środkiem komunikacji jest także ich własne ciało. Można tu mówić o szczególnej elokwencji ciała. To ciało wyraża często o wiele więcej, aniżeli zdolne są wyrazić słowa, których zasób u dzieci jest stosunkowo ubogi. Myślę, że przy całej kontrowersyjności pedagogiki Rudolfa Steinera uznać należy dużą pedagogiczną wartość stworzonej przez niego i w szkołach waldorfskich uprawianej eurytmii, trafnie określanej jako „widzialny śpiew”.

Twórcza działalność dzieci i młodzieży może także stać się formą ich własnej odpowiedzi na pytania zawarte w dziełach sztuki. W szkołach polskich popularne są zajęcia, na których dzieci dokonują malarskiej interpretacji utworu muzycznego. Podejmuje się także - chociaż już nie tak często - próby malarskiej interpretacji (nie: ilustracji!) poezji. Może także zamiast ciągle jeszcze na lekcjach literatury przez nauczyciela zadawanego pytania: „Co poeta chciał powiedzieć w swoim wierszu?” zachęcić ucznia: „Zatańcz ten wiersz!"? Może nauczyciel - dlaczego nie? - wspólnie z uczniami zatańczy ten wiersz? I może właśnie wtedy - dopiero wtedy! - również on, nauczyciel, uchwyci zawarte w wierszu przesłanie i także jego ogarnie - powołajmy się na Fryderyka Schillera - „owo cudowne wzruszenie, na które rozsądek nie znajduje pojęcia ani język wyrazu”"14.

Koniecznie i to jednak powiedzieć należy, że wybieramy i kochamy sztukę dlatego, że dostarcza ona szczególnej, jedynej w swoim rodzaju przyjemności. Niełatwo tę przyjemność zdefiniować. To jednak, jak sądzę, powiedzieć można, że jest ona organiczną właściwością i naturalną konsekwencją przeżycia dzieła sztuki. Dopowiedzmy więc: właśnie to, że sztuka takiej przyjemności dostarcza, że jest - po prostu - zabawna, także o jej wychowawczej wartości rozstrzyga. Badania wykazują, że sztuka - zwłaszcza dla młodzieży - jest atrakcyjna wychowawczo, ponieważ jest równocześnie atrakcyjną rozrywką ${ }^{15}$. To właśnie ten naturalny (tak!) związek rozrywko-

\footnotetext{
${ }^{14} \mathrm{~F}$. Schiller, Listy o estetycznym wychowaniu człowieka i inne rozprawy, przeł. I. Krońska, J. Prokopiuk, wstępem opatrzył J. Prokopiuk, Warszawa 1972, s. 105. 1986.

${ }^{15}$ Por.: H. Depta, Fabryka snów czy szkoła życia. Problemy młodzieży a wartości filmu, Warszawa
} 
wej i wychowawczej wartości sztuki stanowi o sile i blasku jej skutecznego pedagogicznie oddziaływania. Rola wychowawcy estetycznego na tym również polega, aby tej siły nie uszczuplić, tego blasku nie zgasić. Zależeć mu powinno na tym, żeby taką rozrywkę można było znaleźć na coraz wyższych piętrach sztuki, także w utworach wymagających większego umysłowego wysiłku. Żeby ten właśnie wysiłek stanowił źródło satysfakcji i radości. Słuchając złożonych, wymagających dużego skupienia, utworów Jana Sebastiana Bacha, możemy w tym właśnie pełnym skupienia akcie znaleźć szczególną rozrywkę. Wychowawca estetyczny zauważyć powinien jednak i to, że można wskazać takie do kultury popularnej zaliczane utwory, które są nie tylko „czystą” rozrywką, ale również głębszą refleksję wzbudzić mogą. To naprawdę dla wychowawcy estetycznego szczęśliwa okoliczność, że wychowanie przez sztukę to takie wychowanie, które jest równocześnie propozycją szlachetnej rozrywki.

Bogatsze doświadczenie i większa wiedza nauczyciela uzasadniają jego pozycję jako przewodnika na drodze do prawdy. Doświadczenie życiowe, słusznie nazywane matką mądrości, potrafi być jednak także matką rutyny oraz schematycznych spojrzeń i ocen. W tej sytuacji młode oczy oraz - chociaż jest to pozornie paradoksalne - właśnie brak doświadczenia mogą sprawić, że w tym poszukiwaniu prawdy nowy i ciekawy kierunek wskaże wychowanek. W ten sposób doświadczenie i wiedza wychowawcy (nauczyciela) wzbogacone zostają o świeżość spojrzenia wychowanka (ucznia). Dzieło sztuki, zawierając tzw. „miejsca niedookreślenia”, raczej stawiając pytania, aniżeli udzielając odpowiedzi, pozwala na różne jego odczytania i oceny. Obowiązkiem wychowawcy jest uznanie i uszanowanie oceny odmiennej od jego własnej. Tym bardziej że - jeżeli na to pozwoli - oryginalnych odczytań zawartego w dziele sztuki przesłania, własnych odpowiedzi na postawione w tym dziele pytania potrafią udzielić także ci, których wychowuje przez sztukę. Wtedy także i jemu, wychowawcy-nauczycielowi, stworzona zostaje szansa nowego spojrzenia na to dzieło. Wtedy także i on - dzięki swojemu wychowankowi właśnie! - jest przez sztukę wychowywany. Wychowując przez sztukę i wychowując się przez sztukę, przezwycięża stereotypy wychowania autorytatywnego. W jego działaniach nie ma miejsca na rutynę, schematyczne spojrzenia i oceny, jedynie słuszne rozwiązania. Chętnie się zgodzę, że takie powinny być działania każdego dobrego nauczyciela. Wychowawca estetyczny czy - jak go nazywa Irena Wojnar - nauczyciel wychowania estetycznego posiada jednak szcze- 
gólną „szansę tworzyć nowe wartości w ludziach, a tym samym w swoim własnym świecie. Szansę tę może wykorzystać tym lepiej, im więcej sam posiada inwencji i wyobraźni, im większą wiedzę i bogatszą wrażliwość"16. Wyobraźnia i wrażliwość są nauczycielowi wychowania estetycznego potrzebne po to, aby „zapalić” swoich wychowanków do sztuki. „Zapali” ich zaś tylko wtedy, gdy sam będzie „płonąć”. Także tylko wtedy „rozpali” wrażliwość i wyobraźnię swoich wychowanków.

\section{Bibliografia}

Depta H., Fabryka snów czy szkoła życia. Problemy młodzieży a wartości filmu, Warszawa 1986.

Friedländer M., O granicach nauki w sztuce, [w:] Pojęcia, problemy, metody współczesnej nauki o sztuce. Dwadzieścia sześć artykułów uczonych europejskich i amerykańskich, wybrał, przekłady przejrzał, wstępem opatrzył J. Białostocki, Warszawa 1976.

Goethe J. W., Refleksje i maksymy, przeł., oprac. i wstępem opatrzył J. Prokopiuk, Warszawa 1977.

Grabska E., Morawska H. (red.), Artyści o sztuce. Od van Gogha do Picassa, wybrały i oprac. E. Grabska i H. Morawska, Warszawa 1962.

Ortega y Gasset J., Dehumanizacja sztuki i inne eseje, przeł. P. Niklewicz, wybrał i wstępem opatrzył S. Cichowicz, Warszawa 1980.

Pociej B., Lutosławski a wartość muzyki, Warszawa 1976.

Pomian K., W błysku reklam, w świetle laserów, „Gazeta Wyborcza” („Świąteczna”), 21-22 marca 2004.

Schiller F., Listy o estetycznym wychowaniu człowieka i inne rozprawy, przeł. I. Krońska, J. Prokopiuk, wstępem opatrzył J. Prokopiuk, Warszawa 1972.

Suchodolski B., Uspołecznienie kultury, wyd. 2 zmienione i powiększone, Warszawa 1947.

Suchodolski B., Współczesne problemy wychowania estetycznego, [w:] I. Wojnar (red.), Wychowanie przez sztukę, Warszawa 1965.

Szuman S., O sztuce i wychowaniu estetycznym, Warszawa 1969.

Tatarkiewicz W., Estetyka starożytna, wyd. 2 przejrzane i uzupełnione, Wrocław-Warszawa-Kraków 1962.

Wojnar I., Teoria wychowania estetycznego - zarys problematyki, wyd. 4, Warszawa 1995.

\footnotetext{
${ }^{16}$ I. Wojnar, Nauczyciel i wychowanie estetyczne, Warszawa 1968.
} 